\title{
Afrofuturism and Transhumanism: New Insights into the African American Identity in Octavia Butler's Dawn
}

\author{
Sami Abdullah Al-Nuaimi ${ }^{1 *}$, Zainor Izat Zainal ${ }^{2}$, Mohammad Ewan Awang ${ }^{2}$ and \\ Noritah Omar ${ }^{2}$
}

${ }^{1}$ Department of English Language and Literature, Al-Buraimi University College, 512 Al-Buraimi, Sohar Street, Oman

${ }^{2}$ Department of English, Faculty of Modern Languages and Communication, Universiti Putra Malaysia, 43400 Serdang, Selangor, Malaysia

\begin{abstract}
Afrofuturism offers visions about different aspects of African Americans' future. Combining the elements of Afrofuturism and Transhumanism can allow new and vast paths to argue about African Americans' future. Octavia Butler (1947-2006) is among those authors who wanted a better future for her people. In Dawn (1987), she presents the future of an African American protagonist - Lilith, whose identity is scientifically fictionalised and intermingled with hope for a better future. This study critically examines the traits and the role of the protagonist. It aims to investigate how Butler's transhumanist protagonist's portrayal is necessary to pursue the demarginalisation of African American's future identity. In this respect, we adopt the Afrofuturistic sense of utilising knowledge and science of Ytasha Womack in discussing Afrofuturism, as well as Nick Bostrom's transhumanistic perspective on the necessity of body enhancements to

ARTICLE INFO

extend humanism.
\end{abstract}

Article history:

Received: 9 March 2021

Accepted: 30 April 2021

Published: 22 June 2021

DOI: https://doi.org/10.47836/pjssh.29.2.13

E-mail addresses:

samialnuaimi76@gmail.com (Sami Abdullah Al-Nuaimi)

zainor@upm.edu.my (Zainor Izat Zainal)

ewan@upm.edu.my (Mohammad Ewan Awang)

nomar@upm.edu.my (Noritah Omar)

*Corresponding author
Keywords: Afrofuturism, Dawn, identity, Octavia Butler, transhumanism

\section{INTRODUCTION}

Dawn is the first novel in Octavia Butler's Xenogenesis trilogy, a collection of three post-apocalyptic science fiction novels, 
republished in 2000 under the title Lilith's Brood. The novel shows the dual effects, positive and negative, of using technology in changing various aspects of humankind's life. Dawn starts with Lilith Iyapo (a black human woman), imprisoned on the Oankali spaceship cell, 250 years after the nuclear war on Earth ends. The Oankali save the Earth as well as some of the human race from dying. Humankind proves to be not worthy of living on Earth alone as they left it uninhabitable because of the nuclear wars. The Oankali are an advanced technological race. They own the ability to perceive genetic biochemistry, and they want to improve their genetic material chains and reshape themselves to save their race from extinction. To achieve their aim, the Ooloi work on manipulating genetic material to modify the human race and use their altered DNA. With Lilith's help, distinguished as the mother and the first brood trainer on Earth, they resolve their goals. The humans rebel against Lilith and the genetic manipulation, insisting on keeping their race as it is. As a punishment for their rebellion, the opposers are sent to Earth without her.

Understanding Butler's representation of the African American Lilith and her experiences of body alteration is imperative in order to rethink the demarginalization of African American future identity. This is conceivable through Afrofuturism and Transhumanism, which share many aspects such as utopia and dystopia of humankind, human transcendence, the effect of science and technology on social structure, future visions, changing the future - having a better one, and evaluation of some new subject matters. Moreover, both care about protecting humanity, ending discrimination, and causing positive changes in humankind's life.

In her book Afrofuturism, Ytasha Womack describes Afrofuturism as a multidisciplinary milieu to envision future possibilities through the black people's experiences and perceptions. She illustrates that Afrofuturism deals with the social effects of technology and scientific innovations' ability to bring an end to the "ism" forever and take care of humanity (Womack, 2013). Accordingly, science and its resulted technology are crucial factors to improve the quality of life.

In the case of Transhumanism, the pioneered transhumanist Nick Bostrom in "Transhumanist Values" writes that transhumanism "promotes an interdisciplinary approach to understanding and evaluating the opportunities for enhancing the humans condition and the human organism opened up by the advancement of technology" (Bostrom, 2005, p. 3). He encourages opportunities to improve human well-being by eradicating illnesses, eliminating needless misery, and growing human mental, physical, and emotional abilities. That is, to remove away the unnecessary discomfort in our lives. Thus, it is a way of new possibilities to have an improved human being through technical development.

In this regard, the transhumanist believes that technology plays a significant role in changing life aspects, such as 
physical, mental, social, and spiritual. Hence, technological futurity is required to heal the past and the present wounds of people, namely the African Americans, and to activate identity and social changes.

An example of Afrofuturism and Transhumanism engagement is Butler's Dawn. Butler (1947-2006) was an African American creative science fiction author. She was considered to be the "grand dame of Afrofuturism" (Bailey \& Jamieson, 2017, p. 5). She was preoccupied with the idea of change, "All that you touch, you change. All that you change, changes you. The only lasting truth is change. God is change" (Womack, 2013, p. 179). Butler's writings reflect interests in reforming and improving the life quality of the individuals and communities on Earth. Besides reading science fiction stories and novels, she learned about biology, psychology, anthropology, sociology, ecology, power relationships, and genetic engineering. Her representation of various themes and unique visions for humankind's futuristic aspects placed her name unforgettable in science fiction's world. Her works imply various matters related to the contemporary United States in general and African Americans, particularly black women. She regarded science fiction as a womb for these topics. Changing bodies, hybridity, treating the 'Other,' and extrapolating the apocalyptic human societies are of her major concern as well (Melzer, 2006). In Dawn, Butler's portrayal of Lilith Iyapo signifies the possibility of a new kind of African Americans formed through body modifications and the acceptance of new conditions due to transformation. Due to genetic engineering, Lilith's new condition places her as a powerful and influential agent to prevent race minorities and rearticulate a new African American identity based on utilising science and technology.

\section{LITERATURE REVIEW}

The African American representation in science fiction is of high complexity, primarily due to the broadness of science fiction. Thus, different scholars focus on various aspects and segments of the model in science fiction. For instance, Langer focused on exploring the relationship between postcolonialism and science fiction, particularly exploring diaspora and locality in the postcolonial science fiction and race, culture, identity, and alien/nation (Langer, 2011). Also, hybridity, nativism, and transgression are of critical importance for African Americans' representation. The complexity of the representation of the African American in science fiction is probably best exemplified in Afrofuturism. Yaszek (2015) relates the formation of Afrofuturism to racism. Thus, race is a critical factor in informing the relations between science and society.

Though Samatar demonstrates the blackness of Afrofuturism, he states that there is a distinction between African American science fiction and African science fiction and the diaspora-locality relationship (Samatar, 2017). Whereas, for Lavender, Afrofuturism is related to creating the 'Other' in science fiction (Lavender, 
2014). The issue of race in science fiction has been largely neglected. At the same time, science fiction has reproduced the existing racial stereotypes. Africans, those of African ancestors and Africa, have been represented as primitive or the 'Other' with primitive tendencies. Therefore, the themes of abduction, displacement, alienation, dehumanization in science fiction serve as a metaphor for the black experience, implying that African Americans in science fiction are often represented as primitive, inhumane, savage, monstrous, and evil (Lavender, 2014).

Butler cannot change the African American's past identity, and she cannot change their history as well. Thus, she fictionalizes Dawn's world and makes Lilith with a futuristic African American identity optimistically away from the marginalised African American's past and presents one with the use of the Transhumanism tendency of modification. Yoo posits that Dawn reverses the transhumanist dystopia (Yoo, 2019). This Transhumanist view means the invalidity of a modern world focused on the perception of accepting adaptation and human transformation. Pretzer (2018) studies how Octavia Butler's Dawn fits Heinlein's definition of science fiction to preserve a distinctly human identity in the face of genetic, social, sexual, emotional, and psychological manipulation and alien race domination. In "Pessimistic Futurism: Survival and Reproduction in Octavia Butler's Dawn," Mann argues in an Afrofuturistic pessimistic context how Lilith plays a vital role in creating a new future for humanity. He discusses Lilith's character as an agent of survival; she works to "subvert the forces of hierarchy - racism, misogyny ... Lilith recasts human survival in terms of adaptation and evolution rather than conservation and maintenance" (Mann, 2018, p. 62). The ideas of 'adaptation' and 'evolution' refer to the potentiality of human transformation, and to keep their existence, and humankind has to change.

The idea of human transformation and bodily modifications may involve some negative aspects of the human's body and life; if these modifications are made out of sufficient needs. There is a sense of fairness from creating differences between people, the modified and the non-modified ones. There is a threat of having an imbalance in human relationships and social statuses. People will not look at the adjusted person like a normal human being like them, although there are similarities in the physical shape. Yet, there are up-normal things that can set the modified person apart from the human species. Thus, there is a significant danger of biological evolution, which will allow the original human species to be expanded. Inequality will be increased among the individuals; such imbalance can be cause for misusing the leading technology for humankind's body enhancement. In this respect, Bostrom states that "some of the inequality-increasing tendencies of enhancement technology with social policies" (Bostrom, 2005, p. 2).

There should be a moral compass that governs and control the transformation process. Accordingly, the negative 
representation of transhumanism in science fiction novels is associated with the fear of human beings' annihilation and being othered as non - human beings. Mirenayat et al. (2017) discuss threats in getting unique qualities using genetic engineering technology in science fiction novels. They question the possibility of human being's extinction due to body transformation and enhancement. Mirenayat et al. (2017) present Bostrom's perspective over such technologies in enhancing the human body. They state that some risks should be anticipated and avoided; these technologies have enormous potential for deeply valuable and humanly beneficial uses. In her thesis, Dunkley (2018) argues three different forms of 'Othering' in Butler's Lilith's Brood: the sexualised, racialised, and naturalised Other. She shows the negative representation of transhumanism through the rejection and the revolution of the non - genetic mutational human beings for Lilith Iyapo's role in leading their new life on Earth. The awakened humans refuse Lilith and accuse her of sleeping with the aliens and being different from the other human beings (Dunkley, 2018).

In "Uncanny Race and Octavia Butler," Rebecca Ross (2017) states that the Xenogenesis series's female protagonists have been minored, devalued, and different. Still, they are a source for radical alterity, overcoming human weaknesses, and ultimate freedom. She also illustrates that the uncanny females in the Xenogenesis series show "an adamant refusal to submit to binary categorisation” (Ross, 2017, p. 2).
Tucker (2007), highlights several critical views over the role of the Oankali and their relationships with humankind, about racism in American society, racial identity, and the neo-slave narrative. He explores Butler's contradictory portrayal of the Oankali captures/ savers for human beings and relates it to humans' relationships. Besides, his study illustrates the duality of the Oankali, rebuilding Earth to be suitable for inhabitation and saving humans to achieve their aims.

\section{FRAMEWORK}

Afrofuturism is a means to re-evaluate and update African Americans' culture by bringing future ideas into consideration and accepting them. Womack states that "Afrofuturism combines elements of science fiction, historical fiction, speculative fiction, fantasy, Afrocentricity, and magic realism with non-Western beliefs. In some cases, it's a total re-envisioning of the past and speculation about the future rife with cultural critiques" (Womack, 2013, p. 9). It is seen "as a way of imagining possible futures through a black cultural lens" (Womack, 2013, p. 9). Afrofuturism is a medium of reassessing the importance of the African American image. It represents the plight of minorities and the battle to reinforce African American's freedom (Kim, 2017).

Transhumanism is a philosophical movement initiated by Julian Huxley (1887-1975), which supports human beings' intellectual and physical enhancements through technology. The transhumanists believe that improving the body by using 
technology liberates it from the natural limitations and makes it in a better condition. For them, the essence of reassessing human beings is advanced technology. These enhancements to the human body and mind will make him superior and give him more abilities to overcome his limitations. In "The Transhumanist FAQ: a general introduction," Bostrom demonstrates that "Transhumanism is a way of thinking about the future that is based on the premise that the human species in its current form does not represent the end of our development but rather a comparatively early phase" (Bostrom, 2003, p. 4).

Afrofuturism and Transhumanism are linked together through utilising advanced technology for useful purposes and through the tendency of change. From an Afrofuturistic point of view, Womack sees great potentiality in modern technology; it is "a double-edged sword, deepening as many divides as they build social bridges ... Early forays into genetics were created to link ethnic physical traits with intelligence" (Womack, 2013, p. 36). Thus, technology can be used in solving social problems like racism and discrimination issues. Afrofuturism sees the possibilities of advanced technology utilised to illuminate African Americans' identity imbalance and transcend it. To Womack, 'change' has a time dimension. Afrofuturism looks "at time as a cycle and use that and the past for change" (Womack, 2013, p. 154). The idea of change here is associated with altering the future time based on and motivated by the desire to avoid past experiences. Therefore,
Womack claims that change stands as a source for imagining a better future than the past, embodied in literature, science fiction, to generate a channel of futuristic proposals for social changes - identity reformation, depending on technological innovations (Womack, 2013). In this respect, Afrofuturism envisions the African Americans' future by presenting the impact of science and technology on reshaping changing their value and role in future time.

From a Transhumanist angle, utilising advanced technology for useful purposes and the desire to change are mingled. Nick Bostrom, the Swedish philosopher, is among those prominent transhumanists who support human enhancements through technology. He places the idea of "enhancing the human condition" in the center of defining Transhumanism (Bostrom, 2005, p. 3). The human body's enhancement involves improving the biological, physical, mental, and emotional capacities of human beings to avoid life discomfort through sciences and its resulting technologies. Bostrom promotes technology to give humanity open chances for changes to eliminate body limitations like aging or mortality. He argues that:

We enhance our natural immune systems by getting vaccinations, and we can imagine further enhancements to our bodies that would protect us from disease or help us shape our bodies according to our desires (e.g. by letting us control our bodies' metabolic rate). Such enhancements could improve the quality of our lives (Bostrom, 2005, p. 4). 
Bostrom believes that the body's enhancements will free it from its natural constraints and place it superior in a better condition. Also, transhumanism is a means to achieve a better quality of life by improving our bodies. In this respect, imagination is an essential factor that allows anticipating some enhancements between pre-and post- transformed human beings. The transformation of the human body will enable him to jump over undesirable biological limitations. A person's value is reconsidered, for himself as we all for others because of these modifications (Bostrom, 2005).

Afrofuturism and Transhumanism are addressed as a revolutionary transition, which adopt modern technologies to gain beneficial qualities. We will explore how technology can be utilised to illuminate and transcend African Americans' future identity. We will reveal how Lilith's body's enhancement is essential to achieve a better social well-being state for herself. Accordingly, to be a better person and overcome the human limits, she needs to transform her state from being unenhanced to an excellent condition. We will show that Lilith needs to change and update herself to overcome her limitations and weakness. That is to say, the enhancement of the protagonist - of African American's originality in the Dawn can help African Americans to beat their biological and social limitations. Besides, we will deal with Lilith's interactions with science and technology to investigate the effects of knowledge and sciences on the future and African Americans' identity through analysing the protagonist's re/actions towards advanced technology. Hence, these can be the reasons to think about Transhumanism and A frofuturism as mediums to discuss the African Americans' future identity demarginalisation.

\section{RESULT AND DISCUSSION}

Butler's Dawn links Afrofuturism and Transhumanism through utilising advanced technology for useful purposes and the tendency of change. Butler tries to envision African Americans' future by presenting the impact of science and technology on reshaping their value and role in future time. We will consider first discussing Lilith's Afrofuturistic-Transhumanism portrayal in Dawn. She is Butler's main character and represents the African American's hope for a better future. To investigate this image, we have to understand that Dawn is not about the struggle between the aliens - Oankali, and human beings. The awakened people should not consider the Oankali as mere enemies or opposers to the human's wishes. They should adopt Lilith's view to spread gene trade genetic engineering as a second chance for humanity in post-apocalyptic circumstances. In this regard, in his discussion over life on Earth, Jdahya tells Lilith that "You'll begin again. We'll put you in areas that are clean of radioactivity and history. You will become something other than you were" (Butler, 2007, p. 34). Humanity has to reconstruct their society, change their bad attitudes towards each other, and avoid misusing 
technology. Therefore, as an influential positive agent, Lilith works differently from the rest of the awakened human beings to revive humanity as one race and establish a new understanding of futuristic African Americans. Her transformed condition and modified genes will also allow her to play a leading role in de-marginalising her identity. Accordingly, Lilith is seen as an operative character in Dawn, trying to rebuild human relationships. Lilith's role represents an African American transhumanist in the future.

As pointed out in the previous discussion, Lilith represents the start of new life, and her role reflects the unique identity formulation of African Americans. She reflects an optimistic vision of reversing science and technology's passive effects to transform her future and boost social status. In this respect, Butler provides an optimistic interpretation of African American futuristic identity by presenting a black female's future and genetic engineering (Mann, 2018). Therefore, Lilith accepts the gene trade with the Oankali and body transformation to gain a better future identity. The futuristic context of Dawn allows Butler to envision new life on Earth and new relationships among humankind. The presentation of gene trade gives Butler a path to speculate the transformed African American persona as a modification for the past and present personality.

Through Lilith's duty on Earth, Butler imagines a new beginning of life and creates a new future for humanity, of equal importance, re/forming the black
Americans' future and identity as led by a black American agent. Moreover, Butler presents Lilith as an agent in creating a new life on Earth to reveal what black Americans can do for humanity than the rest of the Americans. In this regard, Dawn was "written in the context of the Reagan administration's twinned wars against poor blacks at home and Soviet enemies abroad" (Mann, 2018, p. 63). Consequently, for the humans' deeds on Earth, they proved to be not worthy of managing their lives on it again the way they like. The Oankali do not trust humans and deprive them of advanced technology 'machines' on the new Earth from the beginning. They need to learn how to use it for useful purposes, rebuilding civilizations than destroying them. Oankali offers them hope for a better future than regression to primitivism; instead, the basics of human life for survival should be learned and respected before. As a result, the future and technology are bound together in shaping humanity's destiny; technology can either create disasters or civilizations according to humankind's manipulations. Thus, the future and technology are in humankind's hands who can decide what role to play and choose what destiny to have; with this in mind, Afrofuturism "advocate(s) of teaching essential survival skills that are necessary for post-apocalyptic circumstances" (Womack, 2013, p. 180). In the same vein, Bostrom (2013) illustrates in an interview with Adam Ford that, in essence, Transhumanism deals with long term issues, which means considering the future, and uses technology 
to become a better person. This view considers the advantages and disadvantages of technology. People can be optimistic about transhumanist visions since there is no misuse of technology. He asserts that one of the main reasons behind establishing the 'World Transhumanist Association' in 1998 is to make people aware of the bio-ethics of human enhancement. Butler refers to the ability of advanced technology is changing the human body through the Ooloi. They represent the capabilities of technology and what technology can do for the sake of humanity. The modifications they do on Lilith's genes are considered to be the solution for many undesirable things for Lilith, overcoming undesirable biological limitations. Furthermore, due to gene transformation, these newly acquired qualities place her in a better status among human beings. Jdahya tells Lilith that:

We've already armed you against the deadlier microorganisms. ... We've strengthened your immune system, increased your resistance to disease in general. ... You've been given health. The ooloi have seen to it that you'll have a chance to live on your Earth — not just to die on it (Butler, 2007, pp. 32-33).

Butler relates what happened to humankind on Earth to two "incompatible characteristics" (p. 38). Jdahya tells Lilith that human beings have two conflicting features, 'intelligence' and 'hierarchy,' which led humankind to their doom:

But what was the problem? You said we had two incompatible characteristics.
What were they? ... You are intelligent, he said. That's the newer of the two characteristics, ... Still, you had a good start in the life sciences, and even in genetics.

What's the second characteristic?

You are hierarchical. That's the older and more entrenched characteristic (Butler, 2007, p. 39).

These human features stand as a solution to their situation, and at the same time, they are obstacles in Lilith's way. Hence, the essence of Lilith's task on Earth is to teach these re-born people to overcome and drop the past beliefs about human differences like racism. Jdahya reveals to Lilith the threats behind misusing science and technology already before. He illustrates the hazard behind these obstacles and what can happen to her life and her people. He compares these threatening features to 'cancer,' and she has to work with the Oankali to eradicate them from society; otherwise, there is no chance for a better future for humankind:

Yes, he said, intelligence does enable you to deny facts you dislike. But your denial doesn't matter. A cancer growing in someone's body will go on growing in spite of denial. And a complex combination of genes that work together to make you intelligent as well as hierarchical will still handicap you whether you acknowledge it or not (Butler, 2007, p. 39).

What makes human beings face extinction is their mis-definition of 
intelligence and hierarchy. For some people, intelligence and hierarchy represent power and sources of continuity and not the sense of humanism, yet they proved the opposite. Working for a better future and ensuring continuity by using technology has played a significant role in influencing relationships between humans on the one hand and humans and technology on the other. Some human beings, groups, races, communities, or cultures use advanced technology to get value, unique qualities, and worthiness to protect their existence and identity. Jdahya goes on elaborating and explaining the solution to these destructive features to Lilith. He tells her the promises of gene trade, suggests the necessity and the limitless possibilities of human enhancements, which can involve different aspects of human life to ensure continuity:

We're not hierarchical, you see. We never were. But we are powerfully acquisitive. We acquire new life-seek it, investigate it, manipulate it, sort it, use it. ... the ooloi can perceive DNA and manipulate it precisely. ... They're like children now, talking and talking about possibilities.

What possibilities?

Regeneration of lost limbs. ... Even increased longevity, though compared to what you're used to, we're very longlived now.

Your people will change. Your young will be more like us and ours more like you. Your hierarchical tendencies will be modified and if we learn to regenerate limbs and reshape our bodies, we'll shares those abilities with you. That's part of the trade. We're overdue for it (Butler, 2007, pp. 41-42).

Jdahya's view reflects Bostrom's encouragement for technological possibilities to free up humans' chance to create improvements that remove body limits such as aging or death. This view also mirrors Womack's idea regarding the erroneous "to link ethnic physical traits with intelligence, thus falsely justifying dehumanization, slavery, and holocausts across the globe" (Womack, 2013, p. 36). Besides, Womack states that "imagination, hope, and the expectation for transformative change is a through line that undergirds most Afrofuturistic art, literature, music, and criticism. It is the collective weighted belief that anchors the aesthetic" (Womack, 2013, p. 42). Similarly, Afrofuturism sees the possibilities of changing the black future by adopting hope, imagination, and expectation for what is better. Her insight into the future can overcome the limits of African Americans' past and present through Lilith's role. For these reasons, Lilith's acceptance of the gene trade will access the limitless future possibilities of predictions to overcome any human vulnerabilities like aging, illnesses, and death and to reach new extents. Accordingly, her action can be seen as a movement promoting technology and intelligence to enhance people's experiences and transform their bodies and lives, namely preferable social status. In addition, Lilith's role is connected with hope for a better future and creating a new world. 
Lilith will accept to take the mission and the responsibility of leading the wakened people on Earth as a human being, despite the consequences of doing so. She tells Jdahya that:

If we have the problem you think we do, let us work it out as human beings. ...

Now it will be done - to the rebirth of your people and mine. No! she shouted. A rebirth for us can only happen if you let us alone! Let us begin again on our own (Butler, 2007, pp. 42-43).

Lilith's discussion with Jdahya reflects the establishment of the African American futuristic identity. Lilith does not feel afraid of Jdahya at the early beginning of the novel. "I don't understand why I'm so ... afraid of you, she whispered. Of the way you look, I mean. You're not that different. There areor were-life forms on Earth that looked a little like you" (Butler, 2007, p. 17). Lilith thinks about the benefits of humankind and does not want to deceive or mislead them:

Better to tell them little or none of that for a while. Better not to Awaken them at all until she had some idea how to help them, how not to betray them, how to get them to accept their captivity, accept the Oankali, accept anything until they were sent to Earth (Butler, 2007, p. 117).

Moreover, Lilith does not want to abandon her fellow humans, believing in the idea that they are all equal as human beings, sharing the same destiny as living together on Earth. She says that: "If we endure this place, behave as though it's a ship no matter what anyone thinks individually, we can survive here until we're sent to Earth" (Butler, 2007, p. 143). Lilith tells them also about the Oankali's plan to reseed Earth with human communities. Besides, "she told them about the gene trade because she had decided they must know. If she waited too long to tell them, they might feel betrayed by her silence" (Butler, 2007, p. 143). So, humans have to think as one group, not individually, to find a way out of their situation and behave themselves; they need to think about one race living on one Earth.

So far, the importance of Lilith's role in changing African Americans' future identity and humanity goes with her trying to utilise Oankali's technology to have a new chance to live again on Earth. In other words, she accepts the gene trade because she believes in the future possibilities behind it and its power in creating new human relationships by which humankind can break down undesired limits from her life. For this reason, on a small scale, employing transforming human beings will liberate themselves, break the restraints of the biological limitations, and reach good social status. The human transformation will generate a new personality, social hierarchy, authority and power, and a new world system on a big scale (Hughes, 2004). Thus, the awakened people have to realise the necessity of gene trade - body transformation, learning to adapt to their new condition, and accepting changes. 
Re-encountering with the humans, Lilith becomes aware that the awakened people will have an opposite perspective regarding the Oankali and the gene trade. After her interaction with Paul Titus the first human Lilith encounters on the Oankali's ship - she realises that there will be a gap for interpreting the relation with the Oankali and agreeing upon human body transformation. Going back to the moment when Lilith saw Paul, she felt with closeness and affection as being another black human male; "She stared at him. A human being - tall, stocky, as dark as she was, clean shaved. He looked wrong to her at first - alien and strange, yet familiar, compelling. He was beautiful" (Butler, 2007, p. 85). This familiarity between two human beings represents Lilith's highest need and priority as being awakened by aliens on their weird spaceship. It is difficult for her to imagine the rest of her life among the Oankali, though she did not feel afraid of them, and they did cause or attempt any harm; they are different.

In comparison to humankind, the Oankali are exotic, unusual, and unattractive. Accordingly, Paul should represent Lilith's desire to spend time and the male to live with. Later on, Paul proves to be similar to Lilith's expectations of 'wrong,' 'alien', and 'strange.' Despite all their sameness, he does not represent a suitable alliance for her. He even beats and tries to rape her after she refuses to have sex with him. Paul acts according to his desires, far away from reason and rationality. He steps away from his humanity. His violence and abuse for
Lilith match the humans' actions towards each other before the nuclear war, and the consequences of his deeds are uncalculated like the result of wars. Nikanj - an Ooloi child, tells Lilith: "He beat you, Lilith, ... He broke your bones. If you had gone untreated, you might have died of what he did" (Butler, 2007, p. 101). Therefore, Paul loses Lilith's companionship and alliance. He fails to see the Oankali like Lilith, and he does not prove their positive role in his life. So, although they are human beings, they are dissimilar, "Lilith quickly comes to terms with her new circumstances on the ship, whereas Paul flatly refuses to abandon the Earthbound human context he experienced as a child" (Mann, 2018, p. 70). They have different future perspectives. In this regard, the sameness and the differences between humankind are not race-bound. Lilith expresses her view about the Oankali, telling Paul that: "Look," she said when he drew back. "I' $m$ not interested in putting on a show for the Oankali." "What difference do they make? It's not like human beings were watching us." "It is to me" (Butler, 2007, p. 94). Butler attempts to show the value of sameness and homogeneity because of human differences. She tries to show the importance of equality through differences, and whatever race or color there is, they are human beings at the end of the day. This proves that to continue on Earth as one race, humankind has to accept each other's differences and accept the Others. Therefore, Paul's refusal to interact with Lilith and the Oankali is related to his refusal to accept the Other. Paul's 
attitude towards the Oankali means that it is not appropriate and acceptable for the aliens or the Others to be present in human life. Besides, his rejection of the Oankali reflects the human's perspective concerning accepting the Other's actions. He does not see any advantages in the Oankali, and they do not represent any hope for a better future or change.

Similar to Paul's attitudes and mistreatment appears against Joseph LiChin Shing, who is killed by the human rebellions - gene trade opposers. Shing is Lilith's companion, partner, lover, and ally. He is of Chinese origin with Canadian citizenship. Joseph resembles Lilith in many aspects: rational, accepting to interact with the Oankali, minor social status, intelligent, and the Nikanj enhances him with unique healing abilities. Thus, like Lilith, he is different from the rest of the awakened human beings; so, he is 'othered' and outcasted by them. Joseph's body modifications widen the gaps between him and the awakened, among other racial issues, which caused him to be violently killed since they no longer treat and consider him as human anymore. Butler pictures the human rebellions' brutality towards the Othered Joseph through Lilith's reaction about their deed:

He had been attacked with an ax.

She stared, speechless, then rushed to him. He had been hit more than onceblows to the head and neck. His head had been all but severed from his body. He was already cold.
The hatred that someone must have felt for him ... Curt? she demanded of Nikanj. Was it Curt? (Butler, 2007, p. 223).

It is a painful and emotionally challenging experience to lose a close person. Curt's violence brings back Lilith's memories of power abuse and controlling each other on Earth. Butler introduces him as

"who had been a cop in New York, and who had survived only because his wife had finally dragged him off to Colombia where her family lived. ... The wife had been killed in one of the riots that began shortly after the last missile exchange" (Butler, 2007, p. 123).

Curt experiences and reflects violence in his life, killing another human being, Joseph, in cold blood. Again, Lilith finds solidarity, care, passion, and harmony with Nikanj, the Ooloi alien, in a grief situation. It comforts her by giving "a new color. A totally alien, unique, nameless thing, half seen, half felt or ... tasted. A blaze of something frightening, yet overwhelmingly, compelling. Extinguished", and then "She walked more willingly with Nikanj now, and the other ooloi no longer isolated them in front or behind" (Butler, 2007, p. 226). Besides, it offers her protection and security against the probable attack of the human gene trade resisters.

As a consequence, Lilith decides to help the Oankali through the Ooloi to keep their race exist. The aliens - different represent 
the solution for her problems against endless with humans disputes. Also, to hope for a better future, open possibilities through boy enhancements, security, and support, the aliens turn to be more human than the humans themselves. Humanity is not the subject of being a human only; it is a manner of life. Humankind has to realise their importance to each other; they have to appreciate each other's values. The Oankali value Lilith's readiness as she realises their mutual influence on each other's existence and continuity. As a result, Lilith represents the saviour for the Oankali and the starter for a new human identity. For Lilith, the humans destroyed Earth and killed people and not the Oankali or their Ooloi.

Thus, the reason behind Lilith's acceptance of the gene trade is Oankali's treatment. Although Jdhaya literally embodies 'unearthliness' (Butler, 2007), and different from the human race, and an 'Other' as an alien, yet she refuses to interact with him. Later she finds the Oankali, the refuge away from humankind's mistreatment and abuse. In other words, she feels safe and protected by the aliens. Besides, she considers the Oankali's gene trade the solution for humans' future problems and the means for a better future life. Lilith looks positively at her awakening and body modifications. In other words, Lilith's refusal for the trade may bring back the humans to the first square of their undeniable, harmful, and painful past, which she does not want. Besides, Lilith's agreement places her differently from awakened human beings.
Furthermore, she is considered an 'Other' since the rest of the awakened human beings refuse the gene trade. They do not want and are afraid of being categorised as 'Others' - becoming non-human beings after the transformation. In other words, they do not want to lose their identity as human beings and to be considered minorities.

Accepting to be an 'Other' is essential in accomplishing her mission, part of her role, and attitudes towards body transformation. Butler familiarises us with Lilith's othering in different events of Dawn. She becomes different from humans because of her biological capabilities due to the genetic mutation by the Ooloi. Lilith has to be empowered by certain features to be influential and effective in carrying on her duties, forming new life and civilization for humanity on Earth. The Oankali modifies her body to have special abilities. She is already othered as black and female, othered as a human among aliens (Oankali), othered as captured and colonised by the Oankali, othered as awakened first, othered as accepting the task of convincing the human binges to make the genetic trade. Being an Other seems to allow Lilith to accustom otherness, which gives her the ability to accept Oankali's plan. At the end of the novel, Lilith lies with the Ooloi and becomes the new race's mother. Hens, Butler's Lilith depiction suggests that being an Other and accepting the Others is the way for hope and change to attain a better rating in life. 


\section{CONCLUSION}

Afrofuturism and Transhumanism are connected by new technologies and the desire to adopt them for useful purposes. In Dawn, we see Butler's vision of how advanced technology is utilised to transcend her protagonist Lilith to play an essential role in filling the social gaps and illuminating African Americans' identity imbalance. Lilith represents hope, intelligence, rationality, and humanity for the sake of humankind. Being black heroin and of African American origin, Lilith represents humans' balanced interaction, the wise use of technology, the value of other humans, the ability to change for something better, and stepping away from being inhuman. All in all, Lilith's character study in the framework of Afrofuturism and Transhumanism demonstrates the positive potential of science and advanced technological paradigms to transform and shape African Americans' future identity.

\section{ACKNOWLEDGEMENT}

We thank our families for their support and our colleagues who provided insight and expertise that greatly assisted the research paper. We would also like to show our gratitude to Pertanika's reviewers and journal officers for their so-called insights. We are also immensely for their comments on earlier versions of the manuscript.

\section{REFERENCES}

Bailey, M., \& Jamieson, A. A. (2017). Guest editors' introduction: Palimpsests in the life and work of Octavia E. Butler. Palimpsest, 6(2), v-xiii.
Bostrom, N. (2003). The transhumanist FAQ: A general introduction (Version 2.1). 2003. World Transhumanist Association. http://www. nickbostrom.com/views/transhumanist.pdf

Bostrom, N. (2005). Transhumanist values. Journal of philosophical research, 30(Suppl.), 3-14. http:// citeseerx.ist.psu.edu/viewdoc/download?doi=10 1.1.635.6455\&rep $=$ rep $1 \&$ type $=$ pdf

Bostrom, N. (2013, March 12). Transhumanism, Risk and the History of WTA [Video]. YouTube. https:// www.youtube.com/watch? $\mathrm{v}=$ VmtrvkGXBn0

Butler, O. E. (2007). Lilith's brood (includes Dawn, Adulthood Rites, Imago). Grand Central.

Dunkley, K. (2018). Becoming-posthuman: The sexualized, racialized and naturalized others of Octavia Butler's Lilith's Brood [Master's thesis, Victoria University of Wellington]. http:// researcharchive.vuw.ac.nz/

Hughes, J. (2004). Citizen cyborg: Why democratic societies must respond to the redesigned human of the future. Basic Books.

Kim, M. (2017). Afrofuturism, science fiction, and the reinvention of African American culture. Arizona State University.

Langer, J. (2011). Postcolonialism and science fiction. Springer.

Lavender III, I. (Ed.). (2014). Black and brown planets: The politics of race in science fiction. Univ. Press of Mississippi.

Mann, J. L. (2018). Pessimistic futurism: Survival and reproduction in Octavia Butler's Dawn. Feminist Theory, 19(1), 61-76. https:// doi.org/10.1177/1464700117742874

Melzer, P. (2006). Alien constructions. Science Fiction and Feminist Thought. University of Texas Press.

Mirenayat, S. A., Bahar, I. B., Talif, R., \& Mani, M. (2017). Beyond human boundaries: Variations of human transformation in science fiction. Theory and Practice in Language Studies, 7(4), 264-272. 
Pretzer, J. (2018). Survival of the fixed-est: Alien invasion of human identity in Octavia Butler's Dawn. The Kabod, 4(2), 5. https:// digitalcommons.liberty.edu/kabod/vol4/iss2/5/

Ross, R. R. (2017). Uncanny race and Octavia Butler. Western Tributaries, 4, 2. https://journals. sfu.ca/wt/index.php/westerntributaries/article/ viewFile/48/26

Samatar, S. (2017). Toward a planetary history of Afrofuturism. Research in African Literatures, 48(4), 175-191. https://static1.squarespace. com/static/57718389725e25272beacd64/t/5f 99913026cfeb07e10e0d19/1603899698260/ Sofia+Samatar+reading+.pdf

Tucker, J. A. (2007). 'The human contradiction': Identity and/as essence in Octavia E. Butler's' Xenogenesis' trilogy. The Yearbook of English Studies, 37(2), 164-181. https://www.jstor.org/ stable/20479308?seq $=1$
Womack, Y. (2013). Afrofuturism: The world of black sci-fi and fantasy culture. Chicago Review Press.

Yaszek, L. (2015). Afrofuturism in American science fiction. In E. C. Link \& G. Canavan (Eds.), The Cambridge Companion to American Science Fiction (pp. 58-69). Cambridge University Press. https://doi.org/10.1017/ CCO9781107280601.007

Yoo, J. (2019). Transhumanist impulse, utopian vision, and reversing dystopia in Margaret Atwood's Oryx and Crake and Octavia E. Butler's Dawn. The Modern Language Review, 114(4), 662-681. https://doi.org/10.5699/ modelangrevi.114.4.0662 